\title{
Impact of Health and Education on Income Inequality: Evidence from Selected Developing Countries
}

\author{
Samina Sabir ${ }^{1}$, Nighat Aziz ${ }^{2}$
}

\begin{abstract}
This paper analyzes the impact of health and education on income inequality in selected developing countries. This study uses panel data for 31 developing countries from 1996 to 2015. We estimated the coefficients by employing the System Generalized Method of Moments (System-GMM) technique due to endogeneity problem. We conclude that education and health significantly contribute to decrease income inequality.
\end{abstract}

Keywords: Health, Education, Income inequality, Panel data, Developing economies

JEL Classification: C23; D31; I14; I24;J24

\section{Introduction}

Income inequality and the resulting deprivation among masses have always remained prominent issues in societies and hence studied by economists, sociologists and anthropologists simultaneously in different perspectives. Income inequality is one of the main social, political and economic issue that seek the attention of the economists and the concerned policy makers.

Empirical research on inequality started in 1950s when Simon Kuznets published his a seminal work on the relationship between economic development and income inequality and found an inverted-U shaped relationship. According to Kuznets, economic inequality is related to the economic development (i.e. income per capita) in a country. However, in the early stages of development, countries haver comparatively equal distribution of income but during the process of industrialization, income inequality increases (Kuznets, 1955).

Kuznets hypothesis explains only a very limited part of the inter-country variation

1 Assistant Professor Department of Kashmir Institute of Economics, University of Azad Jammu $\mathbb{E}$ Kashmir, Pakistan.Email: samina.sabir78@gmail.com

2 M. Phil Scholar Department of Kashmir Institute of Economics, University of Azad Jammu $\mathcal{E}$ Kashmir, Pakistan.Email: nighataziz8@gmail.com

ARTICLE HISTORY
\begin{tabular}{ll}
5 Apr, 2018 Submission Received & 9 May, 2018 First Review \\
\hline 9 Oct, 2018 Second Review & 25 Nov, 2018 Third Review \\
\hline 5 Dec, 2018 Accepted
\end{tabular}


in income distribution (Bulir \& Gulde, 1995). For instance, there is a no evidence of Kuznets curve for African countries (Fields, 2000). Therefore this relationship is not universally acceptable and it is challenging (Ram, 1988; Ravallion, 2004). Some studies support the Kuznets inverted U-Shaped hypothesis (De Gregorio and Lee, 2002; Nielsen and Alderson, 1995; Oswang, 1994; Ali, 1998; Milanovic, 1994; Fishlow, 1995). In contrast, the theoretical as well as empirical researches have shown positive, negative and inconclusive relationships between income inequality and development for many developed as well as developing countries (Deininger \& Squire, 1998; Barro, 2000).

Empirical studies highlight many factors that affect income inequality to a smaller or larger extent. For example, financial development, the size of government's expenditure, inflation, population, unemployment, globalization, and economic growth affect income inequality. A higher value of a certain factor causes higher or lower inequality relies upon the structure of the economic system and the overall level of development of the nation being referred (Cornia \& Kiiski, 2001).

Besides aforementioned factors, human capital in the form of education and health also seems to play a major role in determining the income inequality. There is a difference between the income of the educated and healthy people compared to the income of uneducated and unhealthy people in developing countries. Health and education play a significant role in work performance and especially earnings of the workers. Some studies investigate the effects of education on individual earnings while others look at the effects on the aggregate distribution of income (De Gregorio $\&$ Lee, 2002). It has been recognized that educational factors such as high enrollment and more equal distribution of education play a significant role in ensuring equal distribution of income (De Gregorio \& Lee, 1999) and the level of human capital particularly education is of greater significance (Eicher \& Garcia-Penalosa, 2001). Therefore the relationship between income inequality and educational expansion is inverted U-shaped. During the initial stages of development, a rise in the level of education increases income inequality because more educated individuals get a high income compared to uneducated individuals. A further improvement in the distribution of educational attainments directly relates to a fairer distribution of income and thus decreases economic inequalities. It goes without saying that education enables individuals to handle technological as well as environmental challenges which in turn enhances their overall productivity. Increase in investment in education increases the skills of worker and empowers them to find higher skilled jobs. This increases the supply of skilled workers, decreases their relative wage and thus income inequality reduces. A constant increase in the supply of skilled workers keep their relative wage constant even in the presence of skill based technological progress (Zakaria \& Fida, 2016). Thus expansion in education improves the overall income distribution. 
The association between income inequality and different levels of education has been extensively studied in literature. There is a negative relation between education and income inequality (De Gregorio \& Lee, 2002). Particularly, the effects of secondary school enrolments have been examined on income inequality. It has been found that higher secondary school enrollments and its academic achievements lead to decrease income inequality (Alderson \& Nielsen, 2002; Barro, 2000). Primary education hardly affects income inequality while expansion in secondary and tertiary education reduces income inequality (Mughal \& Diawara, 2011). Education is one of the main factors that influences the income inequality and also one of the basic policy measure to grasp equal income distribution as well as to achieve a stable and democratic society (De Gregorio \& Lee, 2002). However, the connection between education and income inequality is not cleared on pure theoretical grounds (De Gregorio \& Lee, 1999).

Like education, health is also considered among the basic sources of productivity and can be an agent quality of labor. Improvement in health may ensure higher life expectancy that may lead to longer working life rewards and achievements to the skilled and educated class. There are evidences that show a strong positive relationship between income and health. A higher income may potentially determine a better health status via access to improved health services, clean drinking water, nutritious diet and better hygiene. Health and education determine higher efficiency and consistency at work that may ensure higher monetary rewards for working people which may reduce the economic inequalities in general and particularly among the working class. Preston (1975) finds that among poor nations, increase in per capita income and income equality are strongly associated with increases in life expectancy; however, the relationship flattens out and is weaker or even missing among the wealthiest nations. This relationship is known as the Preston curve which states that nations with a more equal distribution of income tend to have higher average life expectancy. This has been investigated further by Rodgers (1979) using data of 50 countries to examine the association between income inequality and life expectancy. The study infers that there is absolutely a negative association between income inequality and life expectancy among countries - with a five to ten year contrast in life expectancy between economically equivalent and unequal societies. Deaton (2003) examines the relationship between income inequality and mortality for a case of rich nations and found no association at all. Ross et al. (2000) observe a positive and significant relationship between mortality and income inequality for urban Canada and United States. However, a negative relationship was observed for OECD countries after controlling for cross country differences in income levels (Wilkinson, 1992; Wilkinson, 1997). For instance, a newborn in a high income nation can expect to live for 75 years, while a newborn in a low income nation can expect to live for just 59 years (World Bank, 2001). The world has made incredible improvements in health and life expectancy 
which explains decreasing income inequality. For instance, in developing world, average life expectancy rose from 40 years in 1950 to 82 years in 2015. Such extraordinary improvements were only possible through enhancements in sanitation, nourishment and primary health care services. Government spending on education and health has shown a statistically significant decreasing impact on income inequality (Claus et al., 2012; Anderson et al., 201). Similarly, Schultz (1963) observes that human capital development is the most vital variable in diminishing economic inequality. There are limited studies that assess the association among education and income inequality (De Gregorio \& Lee, 2002) but neglect the role of health on income inequality in developing countries due to non-availability of data. The present study is an attempt to fill that gap in the existing literature, particularly for developing economies. This study is unique in the sense that it splits human capital into education and health in order to study their individual impacts on income inequality using panel data of developing countries over the time period 1996 to 2015.

There exists a problems of heteroscedasticity, serial correlation, omitted variable bias and endogeneity in the human capital and other control variables. Therefore System Generalized Method of Moment of Arellano and Bond (1995) and Blundell and Bond (1998) is used to fixed these econometric problems.

The remainder of the paper is organized as follows: Section 2 presents the methodology and data that includes econometric modeling, research methods and variables' description. Section 3 discusses the empirical results and Section 4 provides the concluding remarks.

\section{Methodology and Data}

We extended the study of De Gregorio and Lee (2002) by including health as an additional measure of human capital. To empirically investigate the impact of health and education on income inequality, the income inequality regression equation can be written in the following form:

$$
\operatorname{Gini}_{\mathrm{it}}=\alpha_{0}+\alpha \mathrm{X}_{\mathrm{i}, \mathrm{t}}+\beta \mathrm{I}_{\mathrm{i}, \mathrm{t}}+\eta_{\mathrm{i}}+\mathrm{v}_{\mathrm{it}}
$$

Where $\mathrm{i}$ is the number of countries ( $\mathrm{i}=1,2 \ldots, 31$ ), $\mathrm{t}$ is the time period (1996 to 2015). Gini ${ }_{\mathrm{it}}$ Gini is the coefficient, $X_{\mathrm{it}}$ is the vector of targeted variables i.e. health and education (as proxies for human capital), $\mathrm{I}_{\mathrm{it}}$ represents the vector of controlled variables such as natural logarithm of GDP per capita, domestic credit to private sector by banks (as proxy for financial development (FD)) and government spending on goods and services, foreign direct investment (FDI), trade openness (Opp) and inflation rate (Inf). It is assumed that $\mathrm{u}_{\mathrm{it}}=\eta \mathrm{i}^{+} \mathrm{v}_{\mathrm{it}} \cdot \mathrm{u}_{\mathrm{it}}$ is the composite error term which includes both individual specific effect ( $\eta$ it) and transient shocks of standard error 
$\left(\mathrm{v}_{\mathrm{i}, \mathrm{t}}\right)$. While $\alpha$ and $\beta$ are the vector of unknown parameters to be estimated.

All variables appearing on the right hand side of equation (1) can be endogenous. Endogeneity problem occurs when the error term is correlated with explanatory variables. If study uses ordinary least square (OLS) in the presence of endogeneity problem, then estimators are biased and inconsistent. To solve the problem of endogeneity, Arellano and Bond (1991) introduced instrumental variable method based on Differenced Generalized Method of Moment. In this method, differenced equation eliminates the individual fixed effect and study uses lagged level variables denoted by $\mathrm{Z}_{\mathrm{i}, \mathrm{t}-\mathrm{s}}$ as instruments for endogenous variables. This study estimates the following dynamic inequality equation

$$
\operatorname{Gini}_{\mathrm{i}, \mathrm{t}}=\beta_{\mathrm{o}}+\beta_{1} \operatorname{Gini}_{\mathrm{i}, \mathrm{t}-\mathrm{t}}+\beta_{2} \mathrm{X}_{\mathrm{i}, \mathrm{t}}+\beta_{3} \mathrm{I}_{\mathrm{i}, \mathrm{t}}+\eta_{\mathrm{i}}+\mathrm{v}_{\mathrm{it}}
$$

To eliminate country specific effect, equation (2) is transformed into first differences.

$$
\Delta \mathrm{Gini}_{\mathrm{i}, \mathrm{t}}=\beta_{1} \Delta \mathrm{Gini}_{\mathrm{i}, \mathrm{t}-\mathrm{t}}+\beta_{2} \Delta \mathrm{X}_{\mathrm{i}, \mathrm{t}}+\beta_{3} \Delta \mathrm{I}_{\mathrm{it}}+\Delta \mathrm{v}_{\mathrm{i}, \mathrm{t}}
$$

The study uses vector of instruments $\mathrm{Z}_{\mathrm{i}, \mathrm{t}-\mathrm{s}}$ to tackle this problem using the following moment conditions based on instruments. $Z_{i, t-s}$

$$
\mathrm{E}\left[\mathrm{Z}_{\mathrm{i}, \mathrm{ts}}\left(\mathrm{u}_{\mathrm{i}, \mathrm{t}}\right)\right]=0 \text { for } \mathrm{s} \geq 2 ; \mathrm{t}=3 ; \ldots ; \mathrm{T}
$$

Where $\mathrm{Z}_{\mathrm{i}, \mathrm{t}-\mathrm{s}}=\left[\mathrm{Gini}_{\mathrm{i}, \mathrm{t}-\mathrm{i}}, \mathrm{X}_{\mathrm{i}, \mathrm{t}-\mathrm{i}}, \mathrm{I}_{\mathrm{it}-\mathrm{i}}\right]$

The difference equation (3) has still the potential problem of endogeneity, though it has eliminated the country fixed effects. In small and finite sample, differenced GMM suffers from weak instrumental problem and thus poor precision. Therefore, Arellano and Bover (1995) and Blundell and Bond (1998) use System Generalized Method of Moment that is an improvement over differenced GMM. In system GMM, GMM is applied on system of equations which consists of first difference equation (3) instrumented with lagged level variables and levels equation (2) instrumented with differenced variables. System GMM is better than difference GMM because it exhibits the smallest bias and variance. It is also a suitable technique for obtaining efficient estimators because it also takes into account the serial correlation problem, heteroscedasticity, omitted variable bias and causality problems (Arellano \& Bover, 1995; Blundell \& Bond, 1998).

Two assumptions are very important for the System GMM that the error terms should be serially uncorrelated and for differenced equation, the error term should not has second order autocorrelation problem. In other words, error terms in differenced equation have significant first order serial correlation $(A R(1))$ and insignificant 
second order correlation (AR(2)) because it implies that moment conditions used are not valid. The Arellano-Bond tests for first order and second order serial correlation are used. For addressing the problem of over-identifying restrictions, Hansen test is used. For robustness check, the study additionally estimates the model using panel random or fixed effect methods. The Hausman test is used to decide between random and fixed effect models.

\subsection{Variables description}

The study uses income inequality (Gini coefficient) as a dependent variable. Here we consider the Gini coefficient based on net income because it includes all transfers and deductions. Gini coefficient is multiplied with hundred. Hence numeric value of Gini coefficient lies between 0 and 100. If the value of Gini coefficient is 0 , it shows perfect equality of income distribution. It implies that all the individuals have equal income. On the other hand, if it is 100 then this shows that one person has all the income and it indicates perfect inequality of income distribution. The value of Gini coefficient is calculated on the basis of Lorenz curve which is graphical representation of income distribution.

Life expectancy at birth is a suitable and generally acceptable measure of population's health (Rodgers, 1979; Leigh \& Jencks, 2007). It is expected that the life expectancy has positive impact on income inequality. As the life expectancy increases, productivity of the worker increases, output increases and then income rises.

Average years of secondary schooling and average years of primary schooling are taken as proxies for education. Education in the form of investment in human capital enables workers to equip with skills and to find skilled based jobs. Therefore human capital accumulation increases the supply of skilled workers, which decreases their relative wage and thus helps in reducing income inequality.

GDP per capita is used as proxy for economic development (Choi, 2006, Shahbaz \& Aamir, 2008; Mughal \& Diawara, 2011; Jauch \& Watzka, 2011; Mushtaq et al., 2014). Increase in per capita income enables people to save more, invest more and earn more income. At initial stage of development, it increases income inequality but at later stage it reduces income inequality.

FDI indicates the flow of capital among nations. The variable is taken in the form of percentage of GDP (Tsai, 1995; Stringer, 2006; Figini \& Gorg, 2006; Chintrakarn et al., 2011). It is expected that FDI decreases inequality due to increase in demand for abundant factor input which is labour in developing countries. This increases employment, income and thus helps in reducing income inequality. 
Trade openness is the aggregate of exports and imports of goods and services measured as a percentage of GDP (Reuveny \& Li, 2003; Shahbaz \& Aamir, 2008; Tian et al., 2008). Trade openness has a negative impact on income inequality, i.e. due to increase in the exports of factor abundant inputs it reduces the economic inequality.

Inflation is used as proxy for macroeconomic stability. Inflation measures the changes in the consumer price index (Mushtaq et al., 2014; Shahbaz \& Aamir, 2008; Kai \& Hamori, 2009; Shahbaz et al., 2007). It is generally expected that inflation has a potentially positive impact on income inequality because inflation hurts more poor than rich. Therefore it enhances income inequality.

Following Jaumotte et al. (2013); Beck et al. (2007) and Demirguc-Kunt and Levine (2009), domestic credit to private sector by banks has been taken as proxy for financial development. The variable has been taken in the form of percentage of GDP. Financial development enables banks and other financial institutions to provide loans to the poor to establish their businesses which decrease income inequality (Banerjee \& Newman, 1993). Furthermore, domestic credit to private sector by banks reduces income inequality through employment channels. If banks give credit to private sector it increases investment which in turn increases employment and income levels. Therefore the overall income inequality drops down. Lastly, the government spending includes government expenditure on goods and services and has been taken in the form of percentage of GDP). The increase in government's investment on goods and services in general and particularly on health and education sectors induces the supply of human capital that may reduce the relative wage and income disparities among the society. ${ }^{3}$

\subsection{Data sources}

The study exploits panel data of 31 developing countries for the time period, 1996 to 2015. The data for the variables such as life expectancy, GDP per capita, foreign direct investment, trade openness and domestic credit to private sector by banks and government spending have been taken from the World Development Indicators (WDI); whereas data on Gini coefficient have been taken from Standardized World Income Inequality Database (SWIID). The data of average years of primary schooling and average years of secondary schooling have been taken from Barro and Lee (2013) database. The data for the years 2014 and 2015 is not available, rather it has been extrapolated. Due to data limitations, thirty-one developing countries have been selected for the analysis by following the World Bank classification. ${ }^{4}$ Descriptive statistics of the variables are given in Table 1. According to Table 1, average value of

3 Correlation Matrix of all variables are given in appendix A

4 See Appendix B for the list of countries 
Table1: Descriptive Statistics

\begin{tabular}{|c|c|c|c|c|c|}
\hline Variable & Obs. & Mean & Std. Dev. & Min. & Max. \\
\hline Gini \% & 620 & 45.830 & 9.087 & 26.884 & 70.820 \\
\hline Life Expectancy (in years) & 620 & 69.426 & 5.701 & 51.557 & 81.788 \\
\hline Primary Schooling (in years) & 620 & 4.732 & 1.254 & 1.770 & 8.880 \\
\hline Secondary Schooling (in years) & 620 & 2.942 & 1.357 & 0.800 & 6.870 \\
\hline lnGDPP & 620 & 9.128 & 0.601 & 7.654 & 10.322 \\
\hline FDI\% & 620 & 3.901 & 4.058 & -5.007 & 43.912 \\
\hline Rate of INF & 620 & 9.477 & 12.442 & -1.418 & 154.763 \\
\hline Rate of FD & 620 & 44.386 & 29.945 & 1.385 & 166.504 \\
\hline Rate of Trade Openness & 620 & 74.763 & 32.812 & 15.636 & 172.185 \\
\hline Government Spending (\%GDP) & 620 & 72.200 & 16.192 & 15.100 & 99.300 \\
\hline
\end{tabular}

Source: Author's own calculated

Gini coefficient is $45.83 \%$ and the income inequality in developing countries ranges from $26.88 \%$ to $70.82 \%$.

Life expectancy a proxy of health index has mean value of 69.43 years with standard deviation 5.70. It ranges between 51.56 and 81.79 years. Average years of primary school education completed is 4.73 with standard deviation 1.25 . It ranges between 1.77 and 8.88 . Similarly, average years of secondary school completed are 2.94 and its range is from 0.8 to 6.87 . Average value or weightage of secondary school

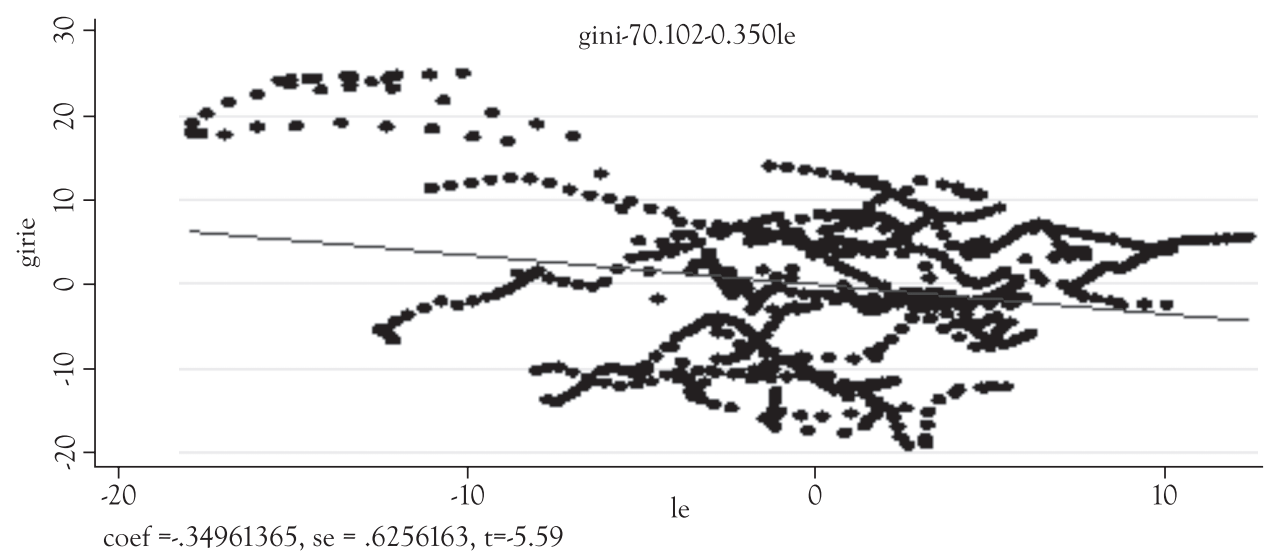

Figure 1: Income Inequality (Gini) and Life Expectancy (le) 
completed is greater than the average value of primary school completed. For instance, the range of average years of primary school completed is greater than average years of secondary school completed in the selected developing countries.

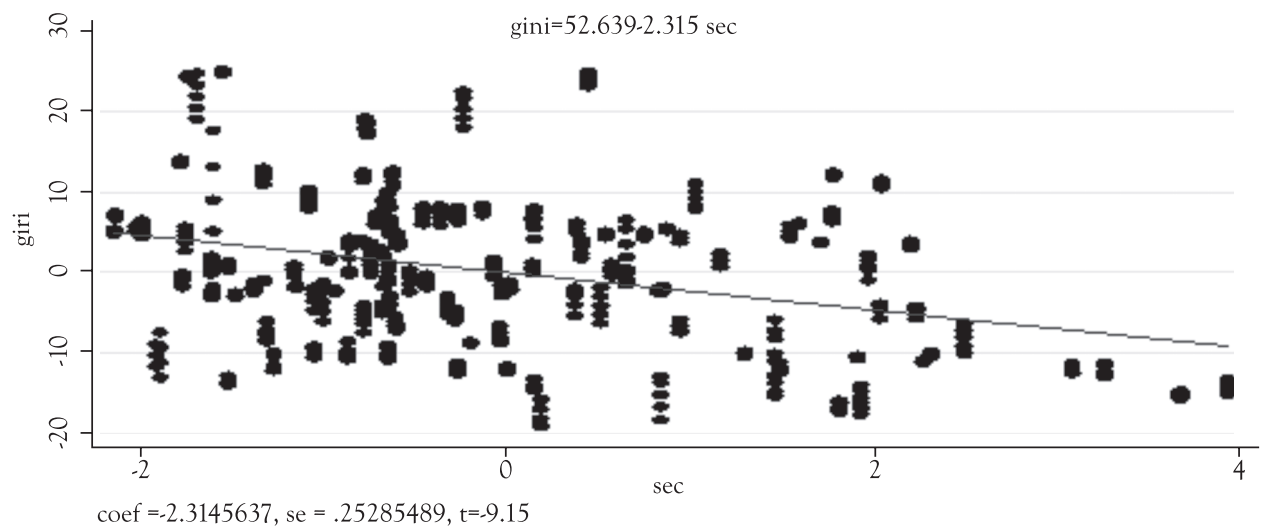

Figure 2: Gini Coefficient (gini) and Average Years of Secondary School Completed (sec)

Table A given in appendix A provides the correlation among the variables. This table shows the moderate correlation between health, education and Gini coefficient. A scattered diagram of income inequality and life expectancy (Fig. 1) shows that income inequality is decreasing with the increase in life expectancy or health index.

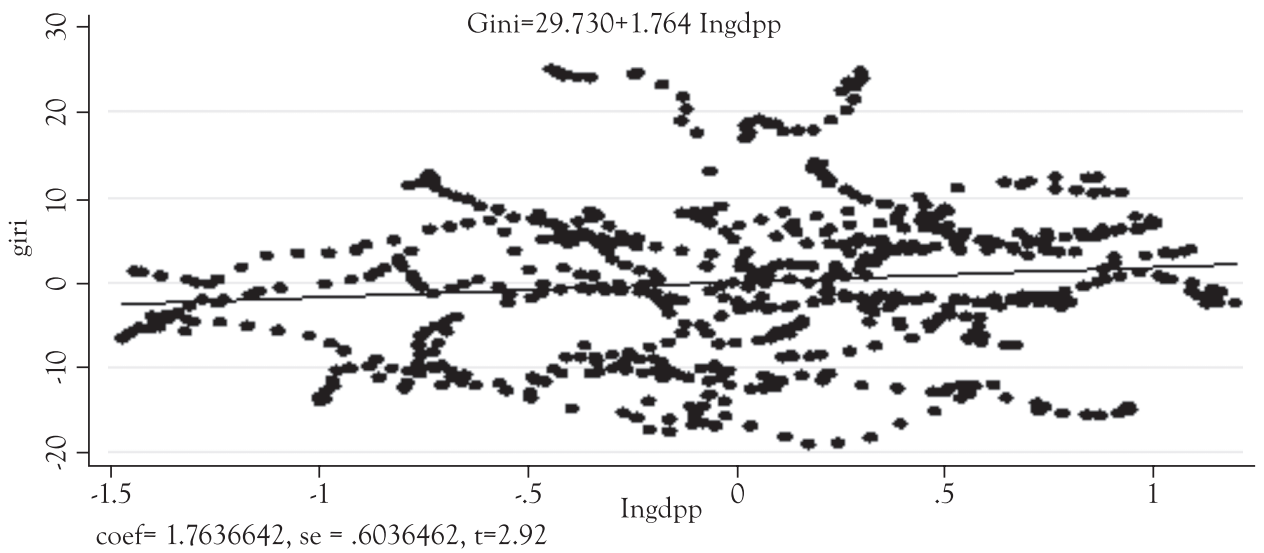

Figure 3: Income Inequality (gini) and lnGDP Per Capita (lnGDPp) 
Whereas scatter diagram of income inequality and average years of secondary school completed (Fig. 2) indicates the negative relationship. This implies that human capital accumulation in developing countries helps in reducing the overall income inequality. Furthermore scatter plot of income inequality and lnGDP per capita (Fig.3) shows that both variables are positively associated.

\section{Data Analysis and Results}

Firstly, the model is estimated with panel random and fixed effect methods. Hausman test is run to decide between random and fixed effects, where the null hypothesis is that the favored model is random effects against fixed effects. The Hausman test statistics is 0.0061 which suggests that it is suitable to use fixed effects model for estimation. Life expectancy and secondary school enrolment are the important variables of interest. The dependent variable of the model is Gini coefficient, a measure of income inequality. When variables are analyzed by fixed effect estimation, life expectancy, secondary schooling, foreign direct investment and trade openness are negatively related with income inequality, which indicates that all these variables decrease income inequality. Due to endogeneity problem in the variables, heteroscedasticity and autocorrelation problem, results of fixed effect model may be biased. Therefore the study employs system GMM and the results are presented in Column 2 of Table 2.

The life expectancy has negative and statistically significant impact on income inequality. This means that an increase in life expectancy or health is related to a decrease in income inequality. Generally speaking, higher life expectancy increases the overall productivity and income of the labor force that mitigates the economic inequality. This finding is consistent with the existing literature (Deaton, 2003; Mellor \& Milyo, 2001; Biggs et al., 2010).

The coefficient of secondary schooling is negative and statistically significant at $5 \%$ level of significance which means that a unit increase in average years of secondary schooling completed is associated with decrease in income inequality and vice versa. Education increases the skills and competencies of individuals and enhances the opportunities of getting a higher salaried job. That implies that a more educated society holds greater welfare. In this manner, average year of secondary schooling leads to lower income inequality in developing nations.

Magnitude of the coefficient of primary schooling tells us that a unit increase in average years of primary education completed increases income inequality by 0.417 percentage points and the estimated coefficient is found to be statistically significant at $1 \%$. The result is comparable with previous findings by Barro (2000), Alderson 
Table 2: Estimation Results of Developing Countries with Income Inequality

\begin{tabular}{|c|c|c|}
\hline \multicolumn{3}{|c|}{ Dep. variable: Gini index } \\
\hline Variables & Fixed effect & System GMM \\
\hline \multirow[t]{2}{*}{ Life Expectancy } & $-0.752^{*}$ & $-0.110^{* *}$ \\
\hline & $(0.000)$ & $(0.018)$ \\
\hline \multirow[t]{2}{*}{ Primary schooling } & $1.331^{* *}$ & $0.417^{* * *}$ \\
\hline & $(0.011)$ & $(0.071)$ \\
\hline \multirow[t]{2}{*}{ Secondary schooling } & $-3.586^{*}$ & $-0.330^{* *}$ \\
\hline & $(0.000)$ & $(0.044)$ \\
\hline \multirow[t]{2}{*}{ Ln(GDP per capita) } & -0.341 & $1.299^{*}$ \\
\hline & $(0.757)$ & $(0.006)$ \\
\hline \multirow[t]{2}{*}{ FDI } & -0.023 & $-0.036^{* *}$ \\
\hline & $(0.480)$ & $(0.025)$ \\
\hline \multirow[t]{2}{*}{ Trade openness } & $-0.017^{* * *}$ & $-0.0074^{* *}$ \\
\hline & $(0.062)$ & $(0.035)$ \\
\hline \multirow[t]{2}{*}{ Inflation } & $0.037^{*}$ & $0.006^{*}$ \\
\hline & $(0.000)$ & $(0.101)$ \\
\hline \multirow[t]{2}{*}{ Government Spending } & 0.014 & -0.002 \\
\hline & $(0.293)$ & 0.253 \\
\hline \multirow[t]{2}{*}{$\mathrm{FD}$} & 0.0004 & -0.004 \\
\hline & 0.966 & $(0.442)$ \\
\hline \multirow[t]{2}{*}{ Gini-1 } & $\ldots \ldots \ldots$ & $0.854^{*}$ \\
\hline & & $(0.000)$ \\
\hline \multirow[t]{2}{*}{ Constant } & $97.559^{*}$ & $4.368^{* * *}$ \\
\hline & $(0.000)$ & $(0.100)$ \\
\hline Number of observations & 620 & 589 \\
\hline Number of countries & 31 & 31 \\
\hline Sargan test & & 1.000 \\
\hline $\mathrm{AR}(1)$ & & 0.004 \\
\hline $\operatorname{AR}(2)$ & & 0.078 \\
\hline
\end{tabular}

Note: Numbers in parenthesis are standard deviation and, $\left({ }^{*}\right),\left({ }^{* *}\right)$ and $\left({ }^{* * *}\right)$ denotes statistical significance at $10 \%, 5 \%$ and $1 \%$ significance level, respectively.

and Nielson (2002), Sylwester (2003), Wells (2006), Mughal and Diawara (2011) and Checchi (2003). Summing up, in general, increase in average years for completing 
primary education has a positive impact on income inequality. We may conclude that the opportunity cost of time spent on completing primary education is high.

The coefficient of natural log of GDP per capita is positive and statistically significant at $10 \%$ level of significance. Similar results have been obtained by Kai and Hamori (2009), Shahbaz and Aamir (2008), Tian et al. (2008) and Mushtaq et al. (2014). We may conclude that for developing economies, the early stages of economic development leads to increase in income inequality (Kuznets, 1955).

Foreign direct investment (FDI) is negatively related with income inequality. This means that an increase in FDI is related to a decrease in income inequality. This result is also supported by Chintrakarn et al. (2011). FDI is related to a decrease in income inequality by utilizing the surplus amount of low-skilled workers in developing countries.

Trade openness is negatively related with income inequality. The Heckscher Ohlin model states that an increase in trade liberalization benefits the abundant factor of production by shifting income towards it. For example, developing countries are rich in labor; therefore they produce and export labor intensive goods. It increases the employment opportunities, which reduces wage dispersions and economic inequalities (Bourguignon \& Morrisson, 1990). Furthermore, trade openness in many developing countries, boosts the real incomes of the unskilled labor force, thereby helping to reduce income inequality and poverty (Anderson, 2005).

The coefficient of inflation is positively related with income inequality. This implies a rise in inflation is identified with an increase in income inequality and vice versa. Similar results have also been obtained by Albanesi (2007), Laidler and Parkin (1975) and Fischer and Modigliani (1978). Inflation worsens income inequality in different ways. For example, an increase in inflation rate effects the poor more than the rich, hence number of poor might also increase as an after effect of inflation in the country, which may enhance income inequality. Furthermore, greater inflation is related to decrease in investment from production side and it might prompt low economic growth and reduction in employment creation. Due to this reason, demand for and real returns to labor might diminish bringing about worse distribution of income in real terms. Moreover, people with fixed nominal incomes may not be able to compensate for the inflationary shocks, their real income thus decreases. However, at the same time real property owners with durable assets (such as land, housing, buildings, etc.) may benefit due to increase in their assets' prices thus leading to an unequal distribution of income (Budd \& Seiders, 2004).

Domestic credit to private sector by banks or financial development $(F D)$ is nega- 
tively (though insignificantly) related with income inequality. This may imply that as financial market develops, the credit constraints faced by low income agents alleviate, which in turn helps to reduce poverty as well as income inequality. The result is in line with the previous findings by Galor and Zeira (1993), Banerjee and Newman (1993), Beck et al. (2007), Kappel (2010), Barro (2000), Batabyal and Chowdbury (2015) and Baligh and Pirace (2012). However, literature indicated ambiguous relationship between financial development and income inequality on pure statistical grounds. Similarly, government spending also affects income inequality negatively but insignificantly. We may conclude that increase in government spending by $1 \%$ reduces income inequality by 0.002 percent. This implies that government investment policies in other developing countries may help in reducing income disparities among the masses.

\section{Concluding Remarks}

The key objective of this paper is to investigate the impact of human capital on income inequality in the given developing economies. As much of the literature advances education when considering the effect of human capital on economic inequality, this paper fills an important gap by splitting human capital into two important factors i.e. education as well as health. Health and education are the main variables of interest for our study. The coefficients of health (life expectancy) and education (secondary school completion years) are found to be negative and statistically significant at 5\% level. Indeed, our analysis suggests that education and health are the two most important factors that may help in reducing income inequality in the selected developing countries. Intuitively, the result obtained might also be applied for other developing economies with similar socio-economic profiles.

The result has a number of policy implications that may motivate future research. Much of the policy effort so far has been directed at promoting and expanding education and health services. As this occurs, the supply of human capital increases and the income inequality drops down, potentially. However, it would be remarkable to empirically examine the impact of inclusive health and inclusive education on income inequality for future research.

\section{References}

Albanesi, S. (2007). Inflation and inequality. Journal of Monetary Economics, 54, 1088-1114.

Anderson, K. and W.J. Martin (2005) Agricultural Trade Reform and the Doha Development Agenda. World Bank Policy Research Working Paper No. 3607.

Alderson, A. S. \& Nielsen, F. (2002). Globalization and the Great U-turn: Income Inequality Trends in 16 OECD Countries. American Journal of Sociology, 107(5), 1244--1299. 
Alderson A. S., \& Nielsen, F. (1995). Income inequality, development, and dualism: results from an unbalanced cross-national panel. American Sociological Review 60, 674--701.

Anderson, E., D’Orey, M. A. J., Duvendack, M., \& Esposito, L. (2017). Does government spending affect income inequality? A meta-regression analysis, Journal of economic surveys, 31(4): 1-27.

Ali, A. A. G. (1998). Dealing with poverty and income distribution issues in developing countries: Cross-regional experiences. Journal of African Economies, 7(2), 77-115.

Anderson, E. (2005). Openness and inequality in developing countries: A review of theory and recent evidence, World Development, 33(7), 1045-1063.

Arellano, M., \& Bond, S. (1991). Some tests of specification for panel data: Monte Carlo evidence and an application to employment equations. Review of Economic Studies, 58(2), 277-297.

Arellano, M., \& Bover, O. (1995). Another look at the instrumental-variable estimation of error-components models. Journal of Econometrics, 68(1), 29-52.

Baligh, N., \& Pirace, K. (2012). Financial development and income inequality relationship in Iran. Middle-East Journal of Scientific Research, 12(7), 906-914.

Banerjee, A. V., \& Newman, A. F. (1993). Occupational choice and the process of development. Journal of Political Economy, 101(2), 274-298.

Barro, R. J. (2000). Inequality and growth in a panel of countries. Journal of Economic Growth, 5(1), 5-32.

Barro, R. J., \& Lee, J. W. (2013). A new data set of education attainment in the world, 1950-2010. Journal of Development Economics, 104, 184-198.

Batabyal, S., \& Chowdhury, A. (2015). Does curbing corruption complement financial development in reducing income inequality? Progress in Development Studies, 15(1),49-72.

Beck, T., Demirguc-Kunt, A., \& Levine, R. (2007). Finance, inequality and the poor. Journal of Economic Growth, 12(1), 27-49.

Biggs, B., King, L., Basu, S., \& Stuckler, D. (2010). Is wealthier always healthier? The impact of national income level, inequality, and poverty on public health in Latin America. Social Science and Medicine $71,266-273$.

Blundell, R., \& Bond, S. (1998). Initial conditions and moment restrictions in dynamic panel data models. Journal of Econometrics, 87(1), 115-143.

Bourguignon, F., \& Morrisson, C. (1990). Income distribution, development and foreign trade: A cross-sectional analysis. European Economic Review, 34(6), 1113-1132.

Budd, E. C., \& Seiders, D. F. (2004). The impact of inflation on the distribution of income and wealth. The American Economic Review, 61(2), 128-138.

Checchi, D. (2003). Inequality in incomes and access to education: a cross country analysis (1960-95). 
Labour, 17(2), 153-201.

Chintrakarn, P., Herzer, D., \& Nunnenkamp, P. (2012). FDI and income inequality: Evidence from a panel of US states, Economic Inquiry, 50(1), 788-801.

Choi, C. (2006). Does foreign direct investment affect domestic income inequality? Applied Economics Letters, 13(12), 811-814.

Claus, I., Martinez-Vazquez, J., \& Vulovic, V. (2012). Government fiscal policies and redistribution in Asian countries. ADB Economics Working Paper Series 310, Manila: Asian Development Bank.

Cornia, G. A., \& S. Kiiski, S. (2001). Trends in income distribution in the post-world war ii period: evidence and interpretation. World Institute for Development Economics (UNU-WIDER), Discussion Paper, No. 89.

Deaton, A. (2001). Health, inequality, and economic development. National Bureau of Economic Research, Working paper No. 8318.

Deaton, A. (2003). Health, inequality, and economic development. Journal of Economic Literature 41(1), $113-158$.

De Gregorio, J., \& Lee, J. W. (1999). Education and income distribution: New evidence from cross-country data. Serie Economia, No.55.Centro de Economia Aplicada, Universidad de Chile.

De Gregorio, J. \& Lee, J. W. (2002). Education and income inequality: New evidence from cross country data. The Review of Income and Wealth, 48(3), 395-416.

Deininger, K., \& Squire, L. (1996). A new dataset measuring income inequality. World Bank Economic Review, 10(3), 565-591.

Deininger, K., \& Squire, L. (1998). New ways of looking at old issues: Inequality and growth. Journal of Development Economics, 57(2), 259-287.

Demirguc-Kunt, A., \& Levine, R. (2009). Finance and inequality: Theory and evidence. NBER Working Paper No. 15275.

Eicher, T., \& Garcia-Penalosa, C. (2001). Inequality and growth: The dual role of human capital in development. Journal of Development Economics, 66(1), 173-197.

Fields, G. S. (2000). The Dynamics of poverty, inequality, and economic well-being: African economic growth in comparative perspective. Journal of African Economies, 9(1), 45-78.

Figini, P., \& Gorg, H. (2006). Does foreign direct investment affect wage inequality? An empirical investigation, University of Nottingham Research Paper No. 29.

Fishlow, A. (1995). Inequality, poverty and growth where do we stand.in, OPS Document Reproduction Series, World Bank, 65.

Galor, O., \& Zeira, J. (1993). Income Distribution and macroeconomics. Review of Economic Studies 
60(1), $135-52$.

Jauch, S., \& Watzka, S. (2011). Financial development and income inequality. CESifo Working Paper Series, No. 3687.

Jaumotte, F., Lall, S., \& Papageorgiou, C. (2008). Rising income inequality: Technology or trade and financial globalization. IMF Working Paper No.08/185.

Kai, H., \& Hamori, S. (2009). Globalization, financial depth, and inequality in Sub-Saharan Africa. Economics Bulletin, 29(3), 2025-2037.

Kappel, V. (2010).The effects of financial development on income inequality and poverty. CER-ETHCenter of Economic Research at ETH Zurich. Working Paper No. 127.

Kuznets, S. (1955). Economic growth and income inequality. American Economic Review, 45, 1- 28.

Laidler, D., \& Parkin, M. (1975). Inflation: A survey. Economic Journal, 85, 741- 809.

Leigh, A. \& Jencks, C. (2007). Inequality and mortality: Long-run evidence from a panel of countries, Journal of Health Economics, 26(1), 1-24.

Mellor, J. M., \& Milyo, J. (2001) Re-examining the evidence of an ecological association between income inequality and health. Journal of Health Politics, Policy and Law, 26, 487-522.

Milanovic, B. (1994). Determinants of cross-country income inequality: An augmented Kuznets hypothesis. In Franicevic, V., Uvalic, M., eds., Equality, Participation, Transition: Essays in Honour of Branko Horvat. London: Macmillan \& Co, pp. 48-79.

Mughal, M., \& Diawara, B. (2011). Explaining income inequalities in developing countries: The role of human capital. Working Papers 2011-2012_2, CATT-UPPA- Universite de Pau et des Pays de l'Adour.

Mushtaq, M., Ahmad, K., Ahmed, S., \& Nadeem, M. (2014). Impact of FDI on income distribution in selected SAARC countries. Journal of Applied Environmental and Biological Sciences, 4(7), 1-10.

Nielson, F., \& Alderson, A. S. (1995). Income inequality, development and dualism: Results from an unbalanced cross-national panel. American Sociological Review, 60(5), 674-701.

Oswang, T. (1994). Economic development and income inequality: A nonparametric investigation of Kuznets U-curve hypothesis. Journal of Quantitative Economics, 10, 139-153.

Preston, S. H. (1975). The changing relation between mortality and level of economic development. Population Studies, 29(2), 231-248.

Ram, R. (1988). Economic development and income inequality: Further evidence on the U-curve hypothesis, World Development, 16 (11), 1371-1376.

Ravallion, M. (2004). Competing concepts of inequality in the globalization debate, World Bank Policy Research (Working Paper No. 3243). 
Reuveny, R., \& Li, Q. (2003). Economic openness, democracy, and income inequality: An empirical analysis. Comparative Political Studies 36(5), 575-601.

Ross, N. A., Wolfson, M. C., Dunn, J. R., J, M. Berthelot, Kaplan, G. A., \& Lynch, J. W. (2000). Relation between income inequality and mortality in Canada and in the United States: Cross sectional assessment using census data and vital statistics, BMJ, 320, 898-902.

Rodgers, G. B. (1979). Income and inequality as determinants of mortality: An international cross-section analysis. Population Studies, 33(2), 343-351.

Schultz, T. (1963). Economic value of education. Columbia university press, New York.

Shahbaz, M., \& Aamir, N. (2008). Direct foreign investment and income distribution: A case study for Pakistan. International Research Journal of Finance and Economics, 21, 7-18.

Shahbaz, M., Aamir, N., \& Butt, M. S. (2007). Rural-urban income inequality under financial development and trade openness in Pakistan: The econometric evidence. The Pakistan Development Review, 46(4), 657-672.

Stringer, J. (2006). Foreign direct investment and income inequality in developing countries: An exploration of the causal relationship using industry level FDI data. The 2006 Annual Midwest Political Science Association Conference

Sylwester, K. (2003). Enrolment in higher education and changes in income inequality. Bulletin of Economic Research, 55, 249-262.

Tian, X., Wang, B., \& Dayanandan, A. (2008). The impact of economic globalization on income distribution: Empirical evidence in China. Economics Bulletin, 4(35), 1-8.

Tsai, P. L. (1995). Foreign direct investment and income inequality: Further evidence. World Development, 23(3), 469-483.

Wilkinson, R. G. and K. E. Pickett (2006). Income inequality and population health: A review and explanation of the evidence. Social Science and Medicine, 62(7), 1768-1784.

Wilkinson, R. G. (1992). Income distribution and life expectancy. British Medical Journal, 304(6820), 165-168.

Wilkinson, R. G. (1997). Income, inequality and social cohesion. American Journal of Public Health, 87, 104-106.

Wells, R. (2006). Education's effect on income inequality: An economic globalization perspective. Globalization, Societies and Education, 4(3), 371-391.

World development indicators. Available at (www.worldbank.org).

Zakaria, M., \& Fida, B. A. (2016). Trade openness and income inequality in China and the SAARC region. Asian Pacific Economic Literature, 30(2), 33-44. 


\section{Appendix A}

\begin{tabular}{|c|c|c|c|c|c|c|c|c|c|c|}
\hline 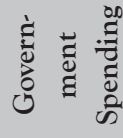 & & & & & & & & & & $\underset{-}{8}$ \\
\hline 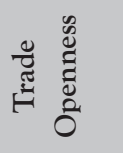 & & & & & & & & & 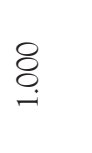 & 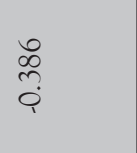 \\
\hline 国 & & & & & & & & $\underset{8}{8}$ & $\begin{array}{l}\stackrel{\infty}{0} \\
\stackrel{0}{0}\end{array}$ & $\begin{array}{l}\tilde{1} \\
\stackrel{0}{0}\end{array}$ \\
\hline 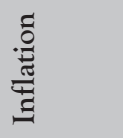 & & & & & & & $\underset{-}{8}$ & $\begin{array}{c}0 \\
0 \\
\vdots \\
0\end{array}$ & $\begin{array}{l}\tilde{\infty} \\
0 \\
\stackrel{0}{1}\end{array}$ & $\begin{array}{l}\infty \\
\infty \\
0 \\
0 \\
0\end{array}$ \\
\hline $\overrightarrow{\theta^{2}}$ & & & & & & \begin{tabular}{l}
8 \\
\hdashline \\
-
\end{tabular} & $\mid \begin{array}{l}\vec{a} \\
\dot{0} \\
\dot{\varphi}\end{array}$ & $\begin{array}{l}n \\
2 \\
0 \\
0\end{array}$ & $\begin{array}{l}\stackrel{+}{+} \\
\text { Oे }\end{array}$ & $\frac{\vec{\infty}}{\overrightarrow{0}}$ \\
\hline 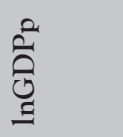 & & & & & 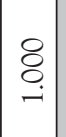 & $\underset{0}{\stackrel{ }{*}}$ & $\mid$\begin{tabular}{l|}
$\vec{\infty}$ \\
0 \\
$\dot{Q}$
\end{tabular} & \begin{tabular}{l} 
in \\
\multirow{2}{*}{} \\
0
\end{tabular} & $\stackrel{0}{\stackrel{0}{0}}$ & $\begin{array}{l}\stackrel{n}{\vec{T}} \\
\stackrel{Q}{i}\end{array}$ \\
\hline 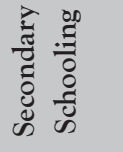 & & & & $\underset{-}{\stackrel{8}{8}}$ & 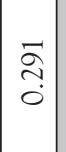 & 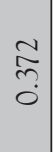 & $\left|\begin{array}{l}0 \\
0 \\
0 \\
0\end{array}\right|$ & $\begin{array}{l}\vec{t} \\
\dot{0} \\
\dot{\varphi}\end{array}$ & 䇏 & $\begin{array}{l}\stackrel{2}{7} \\
\stackrel{7}{Q}\end{array}$ \\
\hline 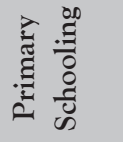 & & & $\underset{-}{8}$ & $\begin{array}{l}n \\
\stackrel{n}{n} \\
0\end{array}$ & $\mid \begin{array}{l}0 \\
0 \\
0 \\
0 \\
0\end{array}$ & $\begin{array}{l}\infty \\
\stackrel{0}{0} \\
0\end{array}$ & $\mid \begin{array}{c}8 \\
\stackrel{9}{9} \\
\dot{0}\end{array}$ & $\underset{\stackrel{f}{J}}{\stackrel{0}{0}}$ & 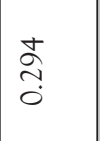 & $\begin{array}{l}\text { Fे } \\
\text { के } \\
\text { iे }\end{array}$ \\
\hline 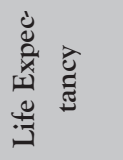 & & $\underset{-}{\stackrel{8}{-}}$ & 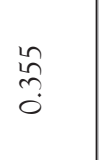 & $\begin{array}{l}0 \\
\stackrel{0}{0} \\
0\end{array}$ & $\mid \begin{array}{l}t \\
0 \\
0 \\
0\end{array}$ & $\begin{array}{l}\tilde{0} \\
0 \\
0\end{array}$ & $\begin{array}{c}\vec{n} \\
\vec{\varphi}\end{array}$ & $\begin{array}{l}\widetilde{\Xi} \\
\dot{0}\end{array}$ & 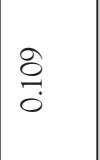 & $\begin{array}{l}\vec{f} \\
\dot{0}\end{array}$ \\
\hline 范 & $\underset{-}{8}$ & $\begin{array}{l}\text { ָे } \\
\text { i̦ }\end{array}$ & $\begin{array}{l}\stackrel{n}{\pi} \\
0 \\
0\end{array}$ & 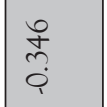 & $\underset{7}{7}$ & 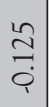 & $\begin{array}{c}\tilde{\sigma} \\
\stackrel{0}{Q}\end{array}$ & $\begin{array}{l}\stackrel{\sim}{*} \\
\tilde{0}\end{array}$ & 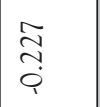 & $\stackrel{亏}{\doteqdot}$ \\
\hline & $\overrightarrow{\tilde{B}}$ & 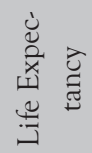 & 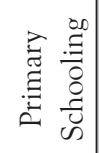 & 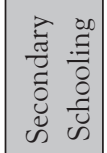 & 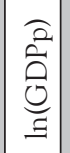 & $\overrightarrow{\overrightarrow{1}}$ & 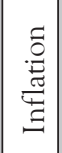 & 呈 & 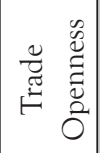 & 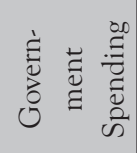 \\
\hline
\end{tabular}




\section{Appendix B}

Table B: List of Developing Countries

\begin{tabular}{|c|c|c|c|}
\hline 1 & Brazil & 17 & Kazakhstan \\
\hline 2 & Bolivia & 18 & Moldova \\
\hline 3 & Bulgaria & 19 & Mongolia \\
\hline 4 & Chile & 20 & Namibia \\
\hline 5 & Colombia & 21 & Pakistan \\
\hline 6 & Costa Rica & 22 & Peru \\
\hline 7 & Czech Republic & 23 & Philippines \\
\hline 8 & Egypt & 24 & Romania \\
\hline 9 & El Salvador & 25 & Russian Federation \\
\hline 10 & Estonia & 26 & South Africa \\
\hline 11 & Ghana & 27 & Thailand \\
\hline 12 & Guatemala & 28 & Tunisia \\
\hline 13 & India & 29 & Turkey \\
\hline 14 & Indonesia & 30 & Uruguay \\
\hline 15 & Iran, Islamic Rep. & 31 & \\
\hline 16 & Latvia & & \\
\hline
\end{tabular}


